were $79 \cdot 4,80 \cdot 9,77 \cdot 6$ and $81 \cdot 2$ respectively. The mixture of proteins in all diets had, therefore, a high biological value which must have been due to supplementation amongst the proteins. Not much more than $40 \%$ of the total proteins in the diets were of animal origin.

3. The true digestibility coefficients of the four diets were $84 \cdot 5,86 \cdot 3,83 \cdot 5$ and $84 \cdot 6$ respectively.
We are indebted to Dr F. Kidd and his staff at the Low Temperature Research Station, Cambridge, for their technical advice in the processing of the food and also for hospitality. Through the courtesy of Dr H. Chick of the Lister Institute, much help was given by Mr G. A. Childs (now Sergeant in the Royal Air Force). We wish to acknowledge the help of Miss B. Cash in the carrying out of the nitrogen metabolism analyses.

\title{
REFERENCES
}

Adolph, W. H. \& Cheng, F. W. [1935]. Chin. J. Physiol. 9, 245.

Aykroyd, W. R. \& Krishnan, B. G. [1937]. Indian J. med. Res. 25, 367.

French, R. B. \& Mattill, H. A. [1935]. Cereal Chem. 12, 365.

Henry, K. M., Kon, S. K. \& Watson, M. B. [1937]. Milk and Nutrition, Part I, p. 37. Reading: Nat. Inst. Res. Dairying.

Lan, T. H. [1936]. Chin. J. Physiol. 10, 637.

Mitchell, H. H. [1924]. J. biol. Chem. 58, 873, 905.
Mitchell, H. H. [1927]. J. Home Econ. 19, 122. \& Carman, G. G. [1926]. J. biol. Chem. 68, 183.

— \& Hamilton, T. S. [1929]. The Biochemistry of Amino Acids. New York: Chemical Catalog Co.

'Student' [1908]. Biometrika, 6, 1.

- [1925]. Metron, 5, 105.

Sumner, E. E. [1938]. J. Nutrit. 16, 129.

Swaminathan, M. [1937]. Indian J. med. Res. 25, 399. [1938]. Indian J. med. Res. 26, 113.

du Toit, B. A. \& Smuts, D. B. [1941]. Onderstepoort J. vet. Sci. 16, 191.

\section{Studies on the Acetone-Butanol Fermentation}

\section{ACETOACETIC ACID DECARBOXYLASE OF CL. ACETOBUTYLICUM (BY)}

\author{
By $\cdot R$. DAVIES, From the Biochemical Laboratory, Cambridge
}

(Received 7 December 1942)

Although the enzyme systems responsible for the fermentation of pyruvic acid and of glucose by $\mathrm{Cl}$. acetobutylicum are so unstable as a whole that, in the absence of the substrate, their activity cannot be preserved in cell suspensions for more than a few hours [Davies, 1942], one enzyme has been found to be extremely stable; this is acetoacetic acid decarboxylase, the enzyme responsible for the decarboxylation of acetoacetic acid to acetone. The quantitative nature of the reaction, its optimum $p H$, and the effect of the age of the cells on their decarboxylase activity, have already been described; also the insensitivity of the enzyme to $\mathrm{O}_{2}$, its ability to withstand acetone, and the fact that it can be extracted cell-free from the acetone powder [Davies, 1942]. In this paper the purification and properties of the isolated enzyme will be described. The parallel isolation of the lysine decarboxylase of Escherichia coli will be published later [Gale \& Epps, 1943].

\section{METHODS}

Preparation of acetoacetic acid. $13 \mathrm{~g}$. of redistilled ethyl acetoacetate were dissolved in $100 \mathrm{ml}$. $N$ $\mathrm{NaOH}$ and kept at room temperature for $40 \mathrm{hr}$.
The ice-cooled solution was acidified with $\mathrm{H}_{2} \mathrm{SO}_{4}$ (25 ml. of $20 \%$ by vol.); the acetoacetic acid was twice extracted with $150 \mathrm{ml}$. ether and the ether evaporated at room temperature. From the residue neutralized with $N \mathrm{NaOH}$ the unchanged ester was removed by extraction with ether; finally the ether was evaporated in vacuo. After standardization by measuring the $\mathrm{CO}_{2}$ evolved when a portion was incubated with acetone-treated cells of $\mathrm{Cl}$. acetobutylicum in Warburg manometers, the concentration was adjusted to $M / 2$.

Preparation of acetone-treated cells. 5 l. flasks containing $4 \frac{1}{2} 1$. of $2 \%$ glucose-liver medium [Davies \& Stephenson, 1941] were sown with $80 \mathrm{ml}$. of a vigorously fermenting culture of $\mathrm{Cl}$. acetobutylicum (BY) on $5 \%$ maize-meal mash, and were then incubated at $37^{\circ}$ until the Rothera acetone test was intense (about $40 \mathrm{hr}$.). The culture was then strained through muslin and the cells collected in a Sharples super-centrifuge. They were washed once on the ordinary centrifuge with about $400 \mathrm{ml}$. distilled water and suspended in 50-100 ml. distilled water. This suspension was blown rapidly from a pipette into 10 vol. of vigorously stirred acetone; after a few minutes the precipitate was collected on a 
Buchner funnel, washed with acetone and with ether, and sucked dry.

\section{Conditions for the determination of enzyme activity}

The optimum substrate concentration, and the optimum $p \mathrm{H}$ for decarboxylation, were determined for both fresh and acetone-treated cells. $Q_{\mathrm{CO}_{2}}$ for the decarboxylation was measured by Warburg manometers.

Effect of substrate concentration. It is seen (Fig. 1) that the affinity of the enzyme for its substrate is fairly low, and is slightly lower for fresh cells than

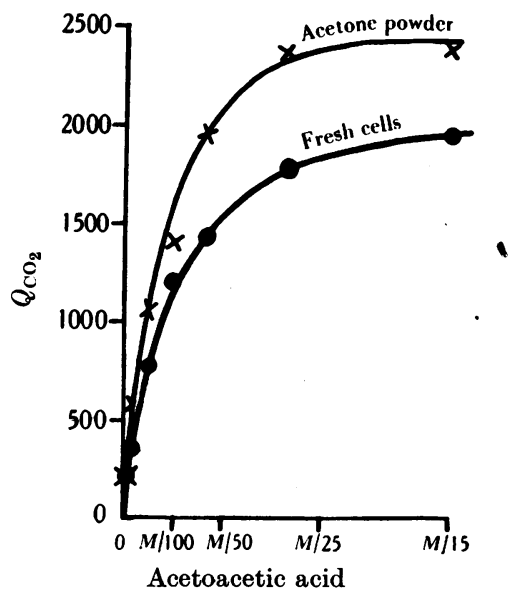

Fig. 1. Effect of substrate concentration on the rate of decarboxylation by fresh and acetone-treated cells. Warburg manometers contained $0.3 \mathrm{ml}$. $2 M$ acetate buffer $p H \cdot 4.5$ (for fresh cells) or $p H$ 5.0 (for acetonetreated cells), sufficient $M / 2$ acetoacetic acid to give concentrations of $M / 15$ to $M / 1000$, and in the side bulb $0.1 \mathrm{ml}$. cell suspension; total vol. $3.0 \mathrm{ml}$; temp. $37 \cdot 5^{\circ}$; gas phase air.

for acetone-treated cells, which require $M / 20$ acetoacetic acid to saturate the enzyme, the half-speed concentration being $0.007 M$.

Effect of $\mathrm{pH}$. This is shown in Fig. 2; curves 1 and 2 were obtained with two different suspensions of fresh cells and the optimum $p H$ differs considerably for the two. The optimum $p \mathrm{H}$ for certain amino-acid decarboxylases of other microorganisms also varies similarly [Gale, personal communication]. The optimum $p \mathrm{H}$ for the decarboxylation by acetone-treated cells is seen to be 5.0.

Estimation of the activity of the enzyme preparations. Conditions of optimum activity were used, the $p \mathrm{H}$ being 5.0 and the final acetoacetic acid concentration $\nless M / 20$. Decarboxylation was measured in Warburg manometers containing in a total volume of $3.0 \mathrm{ml}$., $0.3 \mathrm{ml}$. $2 M$ acetate buffer of $p H 5.0$ and $0.5 \mathrm{ml} . M / 2$ acetoacetic acid; the gas space contained air and the temperature was $37 \cdot 5^{\circ}$.
The rate of $\mathrm{CO}_{2}$ evolution has been correlated with the $\mathrm{C}$ content of the enzyme preparations, determined by the method of Van Slyke \& Folch [1940], and the activities are expressed as $\mu \mathrm{l}$. $\mathrm{CO}_{2} / \mathrm{hr} . \times$ mg. C, called $Q_{\mathrm{CO}_{2}}^{\mathrm{C}}$. One enzyme unit (E.U.) has

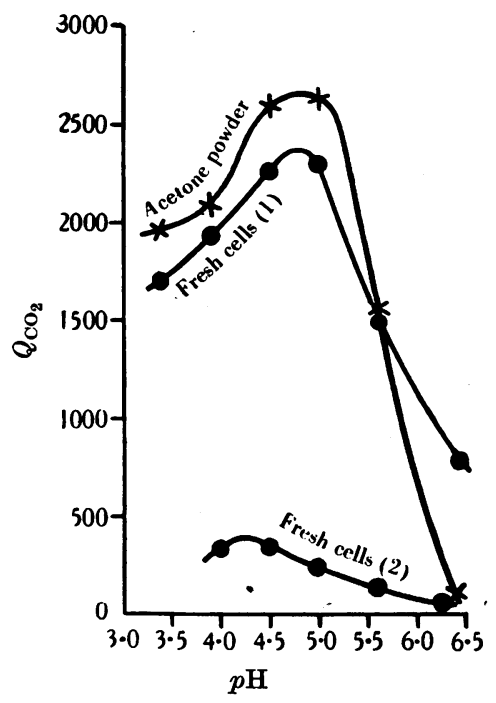

Fig. 2. Effect of $p \mathrm{H}$ on the rate of decarboxylation by fresh and acetone-treated cells. Warburg manometers contained $0.3 \mathrm{ml} .2 M$ acetate buffer of the desired $p \mathrm{H}$, $0.5 \mathrm{ml} . M / 2 \mathrm{Na}$ acetoacetate, and in the side bulb $0.1 \mathrm{ml}$. cell suspension (for fresh cells $4.4 \mathrm{mg}$. dry wt. cells $/ \mathrm{ml}$; for acetone-treated cells $5 \mathrm{mg}$. acetoné powder $/ \mathrm{ml}$.); total vol. $3.0 \mathrm{ml}$; temp. $37 \cdot 5^{\circ}$; gas phase air.

been defined as the amount which will liberate $100 \mu \mathrm{l} . \mathrm{CO}_{2}$ in $5 \mathrm{~min}$. at $37 \cdot 5^{\circ}$ under the optimum conditions.

\section{Extraction of the enzyme}

Distilled water at $37^{\circ}$ was the most satisfactory extractant. The $p \mathrm{H}$ was not critical but at $p \mathrm{H} 4 \cdot 0$ extraction became very poor (Table 1). Prolonged

\section{Table 1. Extraction of the enzyme}

$5 \mathrm{mg}$. of acetone-treated cells were incubated for $4 \mathrm{hr}$. at $37^{\circ}$ with $5 \mathrm{ml}$. of the following: (a) distilled water, $(b) 0.9 \% \mathrm{NaCl}$, (c) $M / 100$ acetate $p \mathrm{H} 4 \cdot 0,(d) M / 100$ acetate $p \mathrm{H} 5 \cdot 0,(e) M / 100$ acetate $p \mathrm{H} 6 \cdot 0,(f) M / 75$ phosphate $p \mathrm{H} 7 \cdot 0,(g) M / 100$ borate $p \mathrm{H} 8 \cdot 0$, (h) $M / 100$ borate $p H \mathrm{H} \cdot 0$. The suspensions were then centrifuged and a suitable portion of the supernatant tested for decarboxylase activity.

$$
\begin{array}{cccccccccc}
\begin{array}{c}
\text { Extracting } \\
\text { agent }
\end{array} & \text { Water } & \begin{array}{c}
0.9 \% \\
\mathrm{NaCl}
\end{array} & \overbrace{4.0} & 5.0 & 6.0 & 7 \cdot 0 & 8.0 & 9 \cdot 0 \\
\begin{array}{c}
\% \text { initial activity ex- } \\
\text { tracted in } 4 \mathrm{hr} \text {. at } 37^{\circ}
\end{array} & 52 & 41 & 6 & 51 & 50 & 38 & 29 & 25
\end{array}
$$

incubation results in bacterial contamination of the acetone powder suspension, hence a few drops of capryl alcohol were added to one half the suspension to check this; it will be seen that whereas in 
$24 \mathrm{hr} .95 \%$ of the enzyme was extracted in the presence of capryl alcohol, $140 \%$ was extracted in its absence (Fig. 3). This extra enzyme could hardly

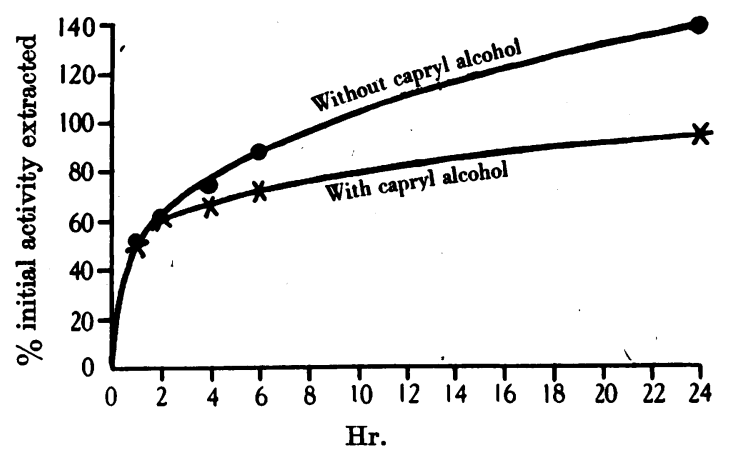

Fig. 3. Rate of extraction of enzyme from acetone powder at $37^{\circ}$. $25 \mathrm{mg}$. acetone-treated cells were suspended in $5 \mathrm{ml}$. water and incubated at $37^{\circ}$; to a similar suspension was added one drop of capryl alcohol, with shaking, and this also was incubated at $37^{\circ}$. Samples were withdrawn at intervals for the determination of decarboxylase activity in the extract.

have resulted from bacterial growth; and it is probable that it was present all the time but that its activity was somehow masked. Fig. 4 shows the variation of the total and of the extractable activity with the temperature of incubation. Heating the suspension to $70^{\circ}$ for $30 \mathrm{~min}$. almost doubled the

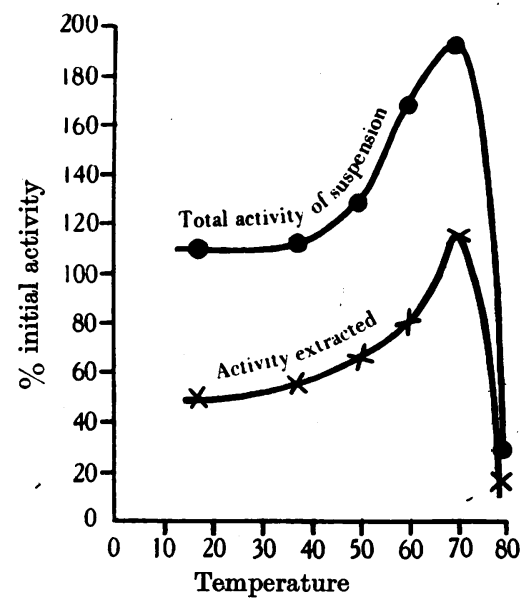

Fig. 4. Variation of total and extractable activity with temperature of incubation. Suspensions containing $60 \mathrm{mg}$. acetone powder in $2 \mathrm{ml}$. water were incubated at various temperatures for $\mathbf{3 0} \mathrm{min}$. and the decarboxylase activity of the extract was then determined.

total activity of the suspension, although at no temperature is more than about half the total activity extractable. This increase in activity cannot be due to production of new enzyme but must be due to freeing of enzyme previously masked. Probably the enzyme is present in the cell in two fractions, one of which is easily extracted and the other fixed to insoluble constituents of the cell from which it can be liberated only with difficulty.

At $70^{\circ}$ (Fig. 5), as at $37^{\circ}$, much activity is extracted very rapidly; for $1 \mathrm{hr}$. thereafter the rate of extraction falls, and later destruction of the

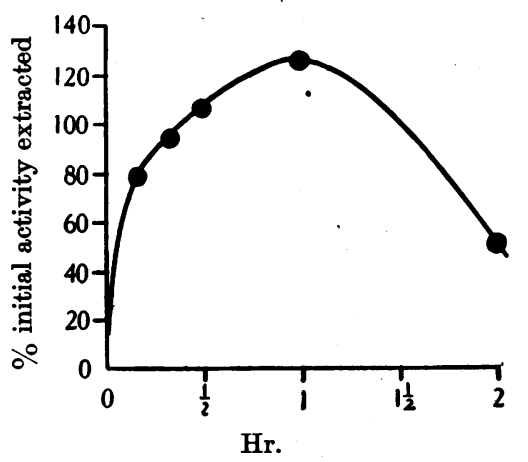

Fig. 5. Rate of extraction of enzyme at $70^{\circ}$. A suspension of $120 \mathrm{mg}$. of acetone powder in $4 \mathrm{ml}$. water was incubated at $70^{\circ}$ and samples were withdrawn at intervals for the determination of decarboxylase activity in the extract.

enzyme sets in. The stability at $70^{\circ}$ varies with different acetone powders. Thus one powder lost $69 \%$ of its activity after $1 \mathrm{hr}$. at $70^{\circ}$. The ease of extractability of the enzyme also varies (Table 2) for unknown reasons.

\section{Table 2. Variation in extractability of the enzyme}

The various acetone powders were incubated at $37^{\circ}$ in aqueous suspension at a concentration of $5 \mathrm{mg} . / \mathrm{ml}$. for the times shown in the table. After incubation the suspensions were centrifuged and the decarboxylating activity of a suitable aliquot of the supernatant determined.

\begin{tabular}{|c|c|c|c|c|c|c|c|c|}
\hline \multirow[b]{3}{*}{$\begin{array}{c}\text { Incubation } \\
\text { time (hr.) }\end{array}$} & \multicolumn{8}{|c|}{ Acetone powder preparation } \\
\hline & $\mathbf{A}$ & & & & & $\mathrm{D}^{*}$ & $\mathrm{E}^{*}$ & $\mathrm{~F}^{*}$ \\
\hline & 1 & 1 & 4 & 1 & 4 & 22 & 24 & 24 \\
\hline $\begin{array}{c}\text { Initial activity } \\
\text { extracted (\%) }\end{array}$ & 62 & 13 & 52 & 43 & 80 & 284 & 22 & 76 \\
\hline Initial $Q \mathrm{co}_{2}$ & 136 & & & 22 & & 1065 & 1030 & 1210 \\
\hline
\end{tabular}

The amount of enzyme extracted is independent of the concentration of the acetone powder suspension within the range $1-30 \mathrm{mg} . / \mathrm{ml}$. With high concentrations, however, the centrifuging of residual insoluble material becomes difficult. $\mathbf{A}$ concentration of $15 \mathrm{mg}$. acetone powder $/ \mathrm{ml}$. seems to. be the most suitable. 


\section{Purification of the enzyme}

Adsorption on to alumina $C \gamma$. The first step in the purification was adsorption on to alumina $\mathrm{C}_{\gamma}$. Of the other adsorbing agents tried, kaolin adsorbed well at $p \mathrm{H} 4 \cdot 0$, and to some extent $(30 \%)$, at

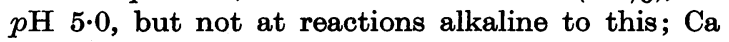
phosphate adsorbed $84 \%$ of the enzyme at $p \mathrm{H} \mathbf{7 \cdot 2}$ while kieselguhr adsorbed $78 \%$ at $p \mathrm{H} \mathrm{4} \cdot 0$. Alumina $\mathrm{C} \gamma$ suspension (13-17 mg. alumina/ml.) possesses several advantages; at $p \mathrm{H} \cdot 5 \cdot 0$ and 6.0 , it adsorbs $70-80 \%$ of the enzyme, but at $p \mathrm{H} 7 \cdot 0$ and above less than $6 \%$. For adsorption, the extract was therefore brought to $p \mathbf{H} \mathbf{5 . 0}$ by the addition of $\frac{1}{20}$ vol. of $2 M$ acetate buffer. An extract derived from an acetone powder suspension of $5 \mathrm{mg} . / \mathrm{ml}$. requires $\frac{1}{10}$ vol. alumina suspension, but with stronger extracts more alumina is required, $0.3 \mathrm{vol}$. being sufficient up to $30 \mathrm{mg} . / \mathrm{ml}$.

Adsorption is very rapid though not instantaneous; $60 \%$ is adsorbed in less than $1 \mathrm{~min},, 89 \%$ in $5 \mathrm{~min}$. and $93 \%$ in $10 \mathrm{~min}$. The rate of elution of the enzyme is very similar. $10 \mathrm{~min}$. was allowed for both processes.

Elution of the enzyme. The alumina was suspended in $M / 5$ phosphate buffer at $p H \mathbf{H} \cdot 0$ and after $10 \mathrm{~min}$. was centrifuged. For maximum elution the volume of eluent should be at least double the volume of alumina suspension used in the adsorption of the enzyme.

Precipitation by ammonium sulphate. Solid $\left(\mathrm{NH}_{4}\right)_{2} \mathrm{SO}_{4}$ was now added to the clear yellow eluate to give $80 \%$ saturation. The solid was used to keep the volume low: $75 \mathrm{~g} . / 100 \mathrm{ml}$. of solvent represents saturation, and other figures are based proportionally. The precipitate was separated by centrifuging and redissolved in a volume of distilled water equal to about $25 \%$ of that of the eluate. Fractional precipitation with $\left(\mathrm{NH}_{4}\right)_{2} \mathrm{SO}_{4}$ failed to separate out the enzyme consistently in any one fraction probably owing to variations in protein impurities. Accordingly it was decided to remove more of the inactive protein before attempting fractional precipitation with $\left(\mathrm{NH}_{4}\right)_{2} \mathrm{SO}_{4}$.

Removal of inactive protein. The addition of $\frac{1}{20} \mathrm{vol}$. of $2 M$ acetate buffer at $p H 4 \cdot 0$ to the solution of the fraction precipitated by $80 \%$ sat. $\left(\mathrm{NH}_{4}\right)_{2} \mathrm{SO}_{4}$ was found to precipitate much of the inactive material; subsequent addition with rapid mixing of $\frac{1}{5}$ vol. of ethanol to the same solution precipitated a further quantity. More ethanol ( $\frac{1}{2}$ vol.), however, inactivates the enzyme.

The enzyme could be recovered from the alcoholic solution by adsorption on to alumina $\mathrm{C} \gamma$ and elution with $M / 5$ phosphate buffer of $p H \mathbf{H} \cdot 0$, using $0 \cdot 3$ vol. of alumina suspension and a volume of phosphate equal to the volume of the preparation before ethanol treatment. For the adsorption with alumina the $p \mathrm{H}$ remained at $4 \cdot 0$.

Fractional precipitation with ammonium sulphate. After the above treatment it was found that most of the enzyme was consistently precipitated in the $50-60 \%$ sat. $\left(\mathrm{NH}_{4}\right)_{2} \mathrm{SO}_{4}$ fraction, and that this was also the purest fraction.

It should be pointed out that the degree of purification obtained in each stage varies considerably from one preparation to another but at the last stage the activity is never less than $Q_{\mathrm{CO}_{2}}^{\mathrm{C}}=200,000$.

To carry purification further much time ànd starting material would be needed. From 6 to $9 \mathrm{~g}$. of acetone-treated cells, which is the entire crop from $18 \mathrm{l}$. of medium, the total amount of protein in the enzyme preparation when an activity of 300,000 is reached, is of the order of $2-5 \mathrm{mg}$., of which 0.5-1.0 mg. is required for a reliable estimation of the $\mathrm{C}$ content. A few further treatments. were, however, tried with variable results. Heating the preparation to $55^{\circ}$ or even to $65^{\circ}$ did not remove any inactive material; a second adsorption of the enzyme on to alumina $\mathrm{C}_{\gamma}$ and elution with $M / 5$ phosphate did not increase activity; concentration of the final preparation, and repetition of the ethanol precipitation at $p \mathrm{H} 4 \cdot 0$, resulted, in one case, in division of the enzyme between the ethanol precipitate and the solution when the precipitate had a slightly increased activity, but in another case most of the activity was lost.

Difficulties in centrifuging the enzyme precipitates. Satisfactory sedimentation of the enzyme at high concentrations of $\left(\mathrm{NH}_{4}\right)_{2} \mathrm{SO}_{4}(60 \%$ and above) presented difficulty. This was especially marked with the more highly purified preparations, and when a $Q_{\mathrm{CO}_{3}}^{\mathrm{C}}$ of $200,000-300,000$ is reached the precipitate formed on $60 \%$ saturation with $\left(\mathrm{NH}_{4}\right)_{2} \mathrm{SO}_{4}$ cannot be separated on the centrifuge at 3500 r.p.m. Such precipitates have to be filtered off through a G4 glass filter, a very slow process. The addition of a drop of capryl alcohol, followed by the thorough removal of dissolved air by evacuation, improves the sedimentation of the precipitates in the earlier stages of the purification, but fails in the final stage.

The final purification procedure. The details of one typical experiment on the purification of the enzyme are set out below :

(1) $5.2 \mathrm{~g}$. of acetone-treated cells (E. $\mathrm{U} .=4260$; $Q_{\mathrm{CO}_{2}}^{\mathrm{c}}=2810$ ) were suspended in about 11 . of distilled water and incubated at $37^{\circ}$ for $4 \mathrm{hr}$. The suspension was centrifuged and $1030 \mathrm{ml}$. of a cloudy yellow extract were obtained (E.U. $=1725 ; Q_{\mathrm{CO}_{2}}^{\mathrm{O}}=$ 1180).

(2) To the extract were added $\frac{1}{20}$ vol. of $2 M$ acetate buffer of $p H \mathbf{H} \cdot 0$ and $\frac{1}{10}$ vol. of alumina $\mathrm{C}_{\gamma}$ suspension (16.7 mg. alumina/ml.). After $10 \mathrm{~min}$. the alumina was spun off and suspended in $203 \mathrm{ml}$. $M / 5$ phosphate buffer of $p H \mathbf{7 \cdot 0}$. After another 
$10 \mathrm{~min}$. this was centrifuged and $203 \mathrm{ml}$. of a clear yellow solution obtained (E.U. $=900 ; Q_{\mathrm{CO}_{2}}^{\mathrm{C}}=7040$ ).

(3) To the eluate were added $120 \mathrm{~g}$. $\left(\mathrm{NH}_{4}\right)_{2} \mathrm{SO}_{4}$ giving $80 \%$ saturation; the centrifuged precipitate gave a yellow solution in $37.5 \mathrm{ml}$. distilled water (E.U. = 710; $\left.Q_{\mathrm{CO}_{2}}^{\mathrm{C}}=45,000\right)$.

(4) To this solution were added $\frac{1}{20}$ vol. $2 M$ acetate buffer at $p H \quad 4 \cdot 0$ and then $\frac{1}{5}$ vol. ethanol, with vigorous shaking. After a few minutes the precipitate was spun off and $11 \mathrm{ml}$. of alumina $\mathrm{C}_{\gamma}$ suspension (strength as above) were added to the centrifugate; after $10 \mathrm{~min}$. the alumina was spun off and the enzyme eluted for $10 \mathrm{~min}$. with $37.5 \mathrm{ml}$. $M / 5$ phosphate buffer at $p H \mathbf{7} \cdot 0$. A clear, slightly yellow solution was obtained (E.U. $=539 ; Q_{\mathrm{CO}_{2}}^{\mathrm{C}}=$ $85,000)$.

(5) To this eluate were added $13 \cdot 6 \mathrm{~g} \cdot\left(\mathrm{NH}_{4}\right)_{2} \mathrm{SO}_{4}$ giving $50 \%$ saturation; the precipitate was spun off and discarded. The centrifugate contained the enzyme (E.U. $=440 ; Q_{\mathrm{CO}_{2}}^{\mathrm{C}}=172,000$ ).

(6) To the centrifugate $2 \cdot 73 \mathrm{~g}$. $\left(\mathrm{NH}_{4}\right)_{2} \mathrm{SO}_{4}$ were added giving $60 \%$ saturation. The precipitate was filtered off and dissolved in $5.2 \mathrm{ml}$. distilled water; the solution contained 181 units of $Q_{\mathrm{Co}_{2}}^{\mathrm{C}}=330,000$. This was the final preparation (Table 3). The most

Table 3. Purification of the enzyme

\section{Treatment}

(1) Original acetone"powder

(2) Aqueous extract

(3) Adsorption on to alumina and elution with $M / 5$ phosphate $p H \mathbf{~ 7 \cdot 0}$

(4) Precipitation by $80 \%$ saturation $.710 \quad 45,000$ with $\left(\mathrm{NH}_{4}\right)_{2} \mathrm{SO}_{4}$

(5) Precipitation by $\frac{1}{5}$ vol. ethanol at $p \mathrm{H} 4.0$ followed by adsorption on to alumina and elution with phosphate

(6) Precipitation by $\left(\mathrm{NH}_{4}\right)_{2} \mathrm{SO}_{4}$ between the limits $50-60 \%$ saturation

$\begin{array}{cc}\underset{\text { Enzyme }}{\text { units }} & Q_{\mathrm{CO}_{2}}^{\mathrm{C}} \\ 4260 & 2,810 \\ 1725 & 1,180 \\ 900 & 7,040 \\ .710 & 45,000 \\ & \\ 539 & 85,000\end{array}$

181330,000 active preparation so far obtained had an activity of 404,000 (but see below on the dissociation of the enzyme).

\section{Properties of the purified enzyme}

Strong solutions of the purest enzyme yet obtained are very slightly yellow, perhaps owing to impurities, since yellow pigments are eliminated at almost every stage of the purification. The ultraviolet absorption spectrum determined in the Spekker spectrophotometer shows a typical protein absorption curve having a maximum at $275 \mathrm{~m} \mu$ and $\log I_{0} / I$ of 2.8 at this wave-length for a solution containing $0.533 \mathrm{mg}$. $\mathrm{C} / \mathrm{ml}$. (about $1 \mathrm{mg}$. protein). All the following experiments were carried out with the enzyme preparation of $Q_{\mathrm{CO}_{2}}^{\mathrm{C}}=404,000$.
(1) Reaction velocity : effect of $\mathrm{pH}$. This was determined in $M / 5$ acetate buffer. The optimum $p H$ is seen to lie at $4 \cdot 9-5 \cdot 0$ (Fig. 6).

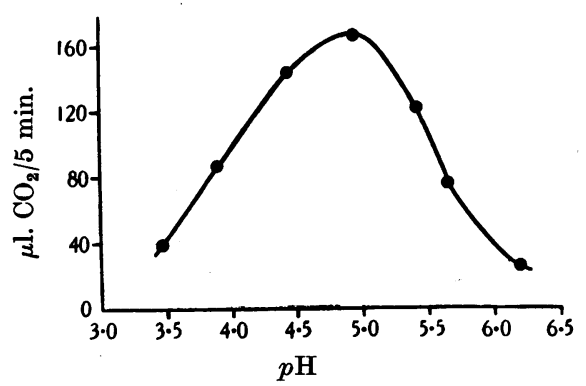

Fig. 6. Effect of $p H$ on the rate of decarboxylation by the purified enzyme. Manometers contained $0.5 \mathrm{ml}$. enzyme solution, $0.3 \mathrm{ml}$. $2 M$ acetate buffer of the required $p H$, $0.5 \mathrm{ml}$. $M / 2 \mathrm{Na}$ acetoacetate; total vol. $3.0 \mathrm{ml}$; temp. $37 \cdot 5^{\circ}$.

(2) Effect of substrate concentration. Fig. 7 shows that the affinity of the enzyme for its substrate is fairly low, a concentration of $0.05 M$ acetoacetic acid being required to saturate the enzyme, the half-speed concentration being $0 \cdot 008 \mathrm{M}$.

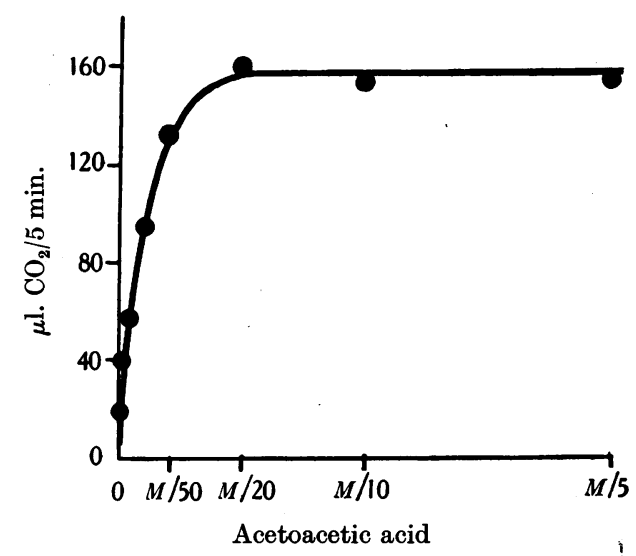

Fig. 7. Effect of substrate concentration on the rate of decarboxylation by the purified enzyme. Manometers contained $0.5 \mathrm{ml}$. enzyme solution, $0.3 \mathrm{ml}$. $2 M$ acetate

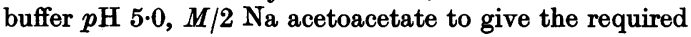
concentration; total vol. $3.0 \mathrm{ml}$.; temp. $37 \cdot 5^{\circ}$.

(3) Effect of temperature. The temperature coefficient increases slightly with rise in temperature (Fig. 8). For the range $20-30^{\circ}$ the $Q_{10^{\circ}}=1 \cdot 82$ and for $30-40^{\circ}$ the $Q_{10^{\circ}}=2 \cdot 16$.

Fig. 9 shows the effect of $5 \mathrm{~min}$. exposure to various temperatures, the activity being determined at $37 \cdot 5^{\circ}$. Little destruction occurs up to $70^{\circ}$; above $70^{\circ}$ the enzyme is rapidly inactivated, being almost completely destrayed in $5 \mathrm{~min}$. at $85^{\circ}$. Inuctivation 
at $60^{\circ}$ occurs at a fairly steady rate (Fig. 10). There was no detectable loss in activity of an aqueous solution that had been stored for 5 weeks in the ice-chest at $4^{\circ}$.

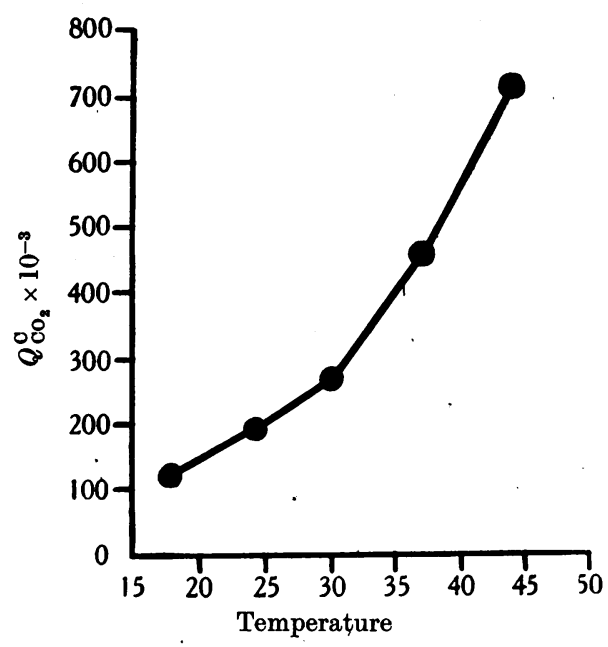

Fig. 8. Effect of temperature on the rate of decarboxylation by the purified enzyme. Manometers contained $0.5 \mathrm{ml}$. enzyme solution, $0.3 \mathrm{ml} .2 M$ acetate buffer $p \mathrm{H}$ $5 \cdot 0,0.5 \mathrm{ml}$. $M / 2 \mathrm{Na}$ acetoacetate; total vol. $3.0 \mathrm{ml}$; temp. as indicated.

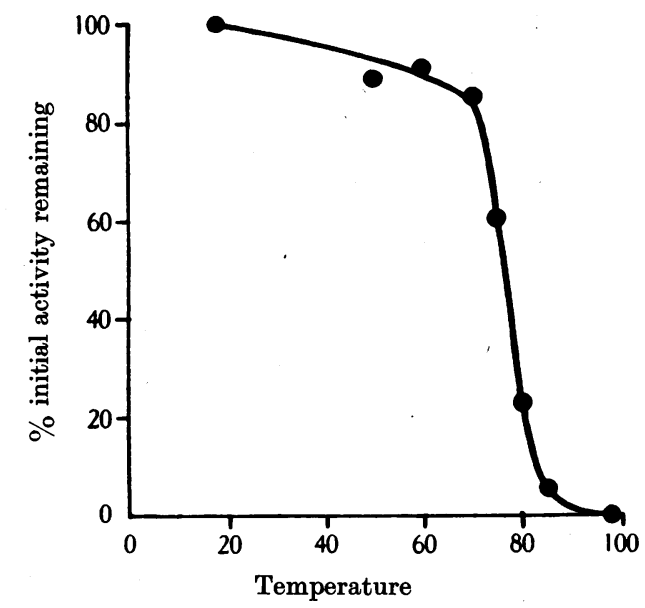

Fig. 9. Effect of temperature on the stability of the enzyme. $1 \mathrm{ml}$. enzyme preparation was heated for $5 \mathrm{~min}$. at the temperatures shown in the figure; $0.5 \mathrm{ml}$. was then used for the determination of activity under the optimum conditions.

(4) Effect of inhibitors. The effects of well-known enzyme inhibitors are given in Table 4. Unlike yeast carboxylase [Green, Herbert \& Subrahmanyan, 1941] the enzyme is comparatively insensitive to $\mathrm{Cu}$, though very sensitive to $\mathrm{Ag}$ and $\mathrm{Hg}$; $\mathrm{KCN}$ is a fairly powerful inhibitor of it and $\mathrm{NaN}_{3}$ inhibits it in high concentrations. $\alpha$-Keto-acids inhibit it to

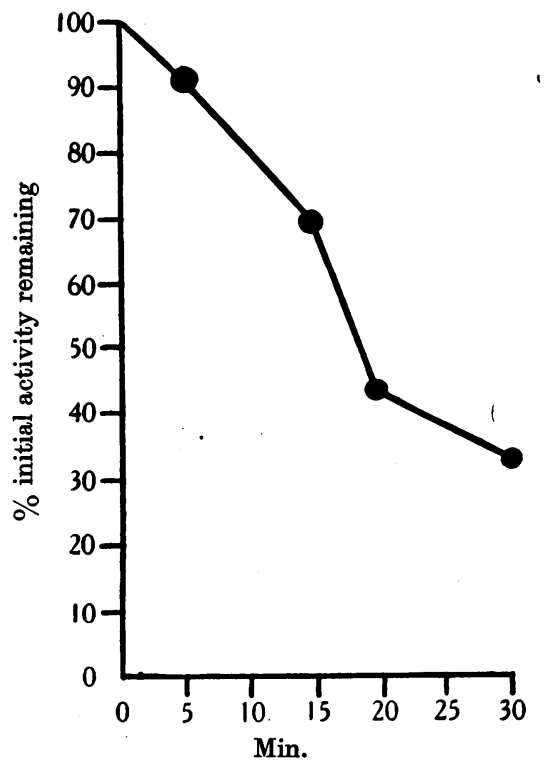

Fig. 10. Effect of time on the activity of the enzyme incubated at $60^{\circ} .4 \mathrm{ml}$. of the enzyme preparation were incubated at $60^{\circ}$ and samples $(0.5 \mathrm{ml}$.) were withdrawn at intervals for determination of decarboxylase activity.

varying degrees and outstanding in this class is acetopyruvic acid which causes $65 \%$ inhibition at a concentration of $M \times 10^{-6}$. The structural relationships between this substance and acetoacetic

Table 4. Effect of inhibitors on decarboxylase activity

Inhibitor

$\underset{M}{\text { Conc. }} \quad \underset{\%}{\text { Inhibition }}$

Heavy metals:

$\mathrm{FeCl}_{3}$

$\mathrm{CuSO}_{4}$

$\mathrm{AgNO}_{3}$

$\mathrm{HgCl}_{2}$

$\begin{array}{rr}10^{-2} & 45 \\ 2 \times 10^{-2} & 41 \\ 10^{-5} & 90\end{array}$

General:

Capryl alcohol

$\mathrm{Na}_{2} \mathrm{~S}$

Urethane

Toluene

$\mathrm{NaN}_{3}$

Iodoacetic acid

KCN

$10^{-5} \quad 100$

Competitive:

Acetone

Methyl ethyl ketone

Acetone dicarboxylic acid

Pyruvic acid

$\alpha$-Ketoglutaric acid

Ethyl acetoacetate

Malonic acid

Oxaloacetic acid

Acetopyruvic acid

$\begin{array}{rr}\text { Satd. sol. } & 0 \\ 10^{-1} & 0 \\ 10^{-1} & 16 \\ \text { Satd. sol. } & 47 \\ 10^{-2} & 53 \\ 10^{-2} & 63 \\ 10^{-4} & 82\end{array}$

$\begin{array}{rr}1 & 10 \\ 1 & 17 \\ 5 \times 10^{-2} & 22 \\ 5 \times 10^{-2} & 64 \\ 5 \times 10^{-2} & 70 \\ 10^{-1} & 72 \\ 10^{-1} & 76 \\ 10^{-2} & 44 \\ 10^{-6} & 65\end{array}$


acid suggest that the inhibition is of a competitive kind, acetopyruvic acid being the most closely related and also the most powerfully inhibitory. The markéd inhibition of acetoacetic acid decarboxylase by low concentrations of acetopyruvic acid disposes entirely of the theory that this substance is an intermediate in the formation of acetone.

(5) Specificity of the enzyme. Table 5 shows that the enzyme is specific for the decarboxylation of acetoacetic acid within the range of substances tested.

Table 5. Specificity of the enzyme

\begin{tabular}{|c|c|c|}
\hline Substrate & $\underset{M}{\text { Conc. }}$ & $\begin{array}{c}\mathrm{CO}_{2} \\
\mu \mathrm{l} . / 5 \mathrm{~min}\end{array}$ \\
\hline Acetoacetic acid & 0.08 & 138 \\
\hline $\begin{array}{l}\text { Ethyl acetoacetate } \\
\text { Pyruvic acid }\end{array}$ & $0 \cdot 1$ & $\begin{array}{l}0 \\
0\end{array}$ \\
\hline $\begin{array}{l}\text { Pyruvic acid } \\
\text { Acetopyruvio acid }\end{array}$ & $\begin{array}{l}0.05 \\
0.05\end{array}$ & $\begin{array}{l}0 \\
0\end{array}$ \\
\hline Oxaloacetic acid & 0.01 & 0 \\
\hline$\alpha$-Ketoglutaric acid & 0.05 & $\mathbf{0}$ \\
\hline Acetone dicarboxylic acid & 0.05 & 0 \\
\hline
\end{tabular}

All the determinations were made in $M / 5$ acetate $p \mathrm{H} \mathrm{5.0.}$

(6) Effect of enzyme concentration. Fig. 11 (curve 1) shows that the reaction velocity increases more rapidly with increasing enzyme concentration than would be expected on the basis of a linear

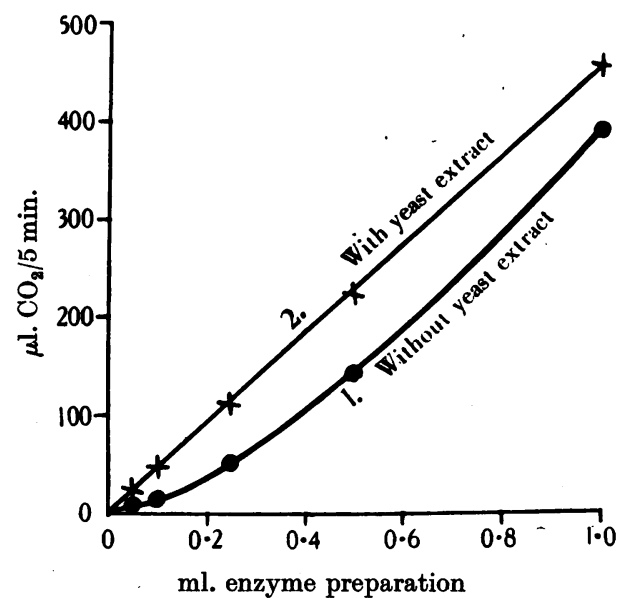

Fig. 11. Effect of enzyme concentration on the rate of decarboxylation. (1) without yeast extract, (2) in presence of yeast extract. Manometers contained $0 \cdot 3 \mathrm{ml}$. $2 M$ acetate buffer $p \mathrm{H} 5 \cdot 0,0.5 \mathrm{ml} . M / 2 \mathrm{Na}$ acetoacetate, $0.5 \mathrm{ml}$. of a boiling-water extract of dried brewer's yeast in one series, and enzyme solution as shown in the figure; total vol. $3 \cdot 0 \mathrm{ml}$.; temp. $\mathbf{3 7 \cdot 5 ^ { \circ }}$.

relationship. This suggests that at low concentrations the enzyme may dissociate into a specific protein and a coenzyme, only the undissociated enzyme being catalytically active. That this is the case is shown by curve 2 where the reaction velocity has been determined in the presence of a boilingwater extract of dried brewer's yeast; here the relationship between enzyme concentration and reaction velocity is linear. Presumably the extract contained the coenzyme in sufficient concentration to counteract the dissociation of the enzyme.

The concentration of enzyme in the region where dissociation is greatest is only about $0.7 \mu \mathrm{g} . / \mathrm{ml}$. and it is in fact only because of the high activity of the enzyme that the dissociation can be observed. As'suming that the enzyme is pure it can be calculated from the curves of Fig. 11 that the dissociation constant for the enzyme is very approximately $1.55 \times 10^{-8} \mathrm{~mol}$./1. This may be compared with the value of $2.5 \times 10^{-7} \mathrm{~mol}$./1. for $d$-amino-acid oxidase [Warburg \& Christian, 1938a].

\section{Attempts to separate enzyme into protein and coenzyme}

The dissociation of the enzyme in low concentrations should make it possible to separate the protein from the coenzyme by dialysis; all attempts so far, however, have been unsuccessful; dialysis for $24 \mathrm{hr}$. at $37^{\circ}$ of $30 \mathrm{mr}$. of a solution containing about $1 \mu \mathrm{g}$. enzyme $/ \mathrm{ml}$. against $4 \mathrm{l}$. of $M / 5$ acetate buffer at $p H 5 \cdot 0$ effected no change in the activity of the enzyme, these conditions being precisely those under which dissociation is observed in the manometer.

Precipitation with ammoniacal $\left(\mathrm{NH}_{4}\right)_{2} \mathrm{SO}_{4}$, which reversibly dissociates yeast carboxylase [Green et al. 1941] does not so dissociate acetoacetic acid decarboxylase. At room temperature, at $45^{\circ}$ for $5 \mathrm{~min}$., at $55^{\circ}$ for $5 \mathrm{~min}$. and at $0^{\circ}$ for $20-40 \mathrm{hr}$., there is a varying loss of activity, but in no case can the activity be restored by adding a boiled suspension of acetone powder or of dried yeast. The same is true after precipitation by $\left(\mathrm{NH}_{4}\right)_{2} \mathrm{SO}_{4}$ in acid solution by the method of Warburg \& Christian [1938b] as described by Weil-Malherbe [1939], while increase in the final acid concentration up to $M / 22 \mathrm{HCl}$ results in a $50 \%$ loss of activity which also cannot be restored. Adjustment of the enzyme solution to $p \mathrm{H} 2$ or $p \mathrm{H} 3$ followed by precipitation with 10 vol. acetone results in complete loss of activity. Finally, $2 \mathrm{ml}$. of enzyme solution were dialysed for $22 \mathrm{hr}$. at $17^{\circ}$ against $800 \mathrm{ml}$. of a solution containing 9 parts $70 \%$ sat. $\left(\mathrm{NH}_{4}\right)_{2} \mathrm{SO}_{4}$ solution and 1 part conc. $\mathrm{NH}_{3}$ solution, and this was followed by dialysis for $1 \mathrm{hr}$. against running tap water. The enzyme was then found to have lost $76 \%$ of its activity, which loss could not be restored by adding boiled cells. It must be assumed in view of these failures to restore the activity of the enzyme that all the above procedures have not caused the enzyme to dissociate but have merely inactivated it. 


\section{The nature of the coenzyme}

Despite the failure to split the enzyme reversibly into a coenzyme and a specific protein, some information as to the identity of the coenzyme has been obtained by studying the reversal of the dissociation that occurs at low enzyme concentrations. As has been shown, yeast extract and an extract of acetone-treated cells can counteract the dissociation, hence the ability of other substances to replace the extracts was investigated. The compounds tested were cocarboxylase, thiamin monophosphate, thiamin, muscle adenylic acid, cozymase $(60-70 \%$ pure), an old preparation of diaphorase containing a considerable proportion as free flavin and, finally, riboflavin had already been shown to be inactive with fair certainty. There remained the first three possibilities. Table 7 shows the effect of boiling, and of hydrolysis in acid and alkali, on the activity of the diaphorase preparation. It is seen that boiling and acid hydrolysis do not alter the activity, but that hydrolysis with alkali causes some inactivation. The first result shows that diaphorase itself cannot be the coenzyme, while the result of acid hydrolysis rules out riboflavin adenine dinucleotide since, under the conditions used, this substance would be hydrolysed into adenylic acid and riboflavin phosphate [Abraham, 1939]. Riboflavin phosphate, however, is not split under these conditions [Kühn \& Rudy, 1936]. Unfortunately it has been impossible to

\section{Table 6. Inhibition of dissociation by various substances}

The manometers contained $0.3 \mathrm{ml} .2 M$ acetate buffer $p H 5.0,0.5 \mathrm{ml} . M / 2$ acetoacetic acid, 0.1 ml. enzyme solution containing about $0.7 \mu \mathrm{g}$. protein; the total vol. was $3.0 \mathrm{ml}$. Temp. $37.5^{\circ}$. The diaphorase preparation contained total flavin equivalent to about $20 \mu \mathrm{g}$. lactoflavin $/ \mathrm{ml}$.

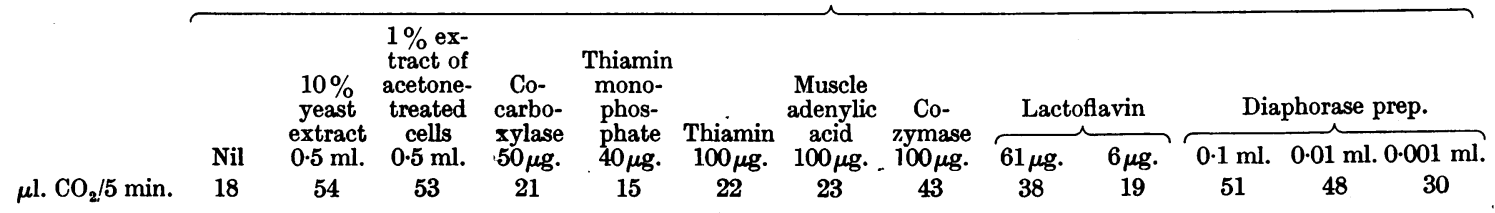

riboflavin. The results (Table 6) show that adenylic acid and the thiamin derivatives are totally inactive, while cozymase and riboflavin exhibit submaximal activity; the diaphorase preparation on the other hand is maximally active at a concentration of $0.0033 \mathrm{ml} . / \mathrm{ml}$. (about $0.07 \mu \mathrm{g}$. riboflavin $/ \mathrm{ml}$.). It is probable that the activity of riboflavin and of the cozymase preparation is due to an impurity, since even large amounts of these substances do not show maximum activity.

The active diaphorase preparation was originally about $90 \%$ pure. There were therefore five possibilities, that the active substance was $(a)$ diaphorase itself, $(b)$ the prosthetic group of diaphorase, riboflavin adenine dinucleotide, (c) riboflavin phosphate, $(d)$ riboflavin, and $(e)$ an impurity in the diaphorase preparation. In view of the small amount of the diaphorase preparation required for maximum activity the last possibility did not seem likely, although it has not yet been excluded, while

Table 7. Effect of boiling and of hydrolysis by acid and alkali on the activity of the diaphorase preparation

The manometers contained the equivalent of $0.1 \mathrm{ml}$. of the diaphorase preparation; the other contents were as described in Table 6.
Treatment of diaphorase ... None $\mu$ l. $\mathrm{CO}_{2} / 5 \mathrm{~min} . \quad 52$

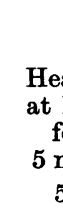

\section{Heated} at $96^{\circ}$

Heated at $100^{\circ} 60 \mathrm{~min}$. for in $N / 20$ $5 \mathrm{~min}$.

50

\section{Boiled} for $\frac{1}{2}$ min. Control, in $N / 10$ no diaHCl NaOH phorase $46 \quad 36$ complete these experiments at the present time, but it seems possible that riboflavin phosphate is actually the coenzyme; the effect of hydrolysis with alkali is evidence in support of this idea.

\section{SUMMARY}

1. The purification and properties of acetoacetic acid decarboxylase of $\mathrm{Cl}$. acetobutylicum have been described.

2. The purified enzyme is quite stable at ordinary temperatures; it is optimally active at $p \mathrm{H} 5.0$ and is specific for acetoacetic acid.

3. In dilute solution the enzyme is dissociated but it has not been possible to separate the component parts.

4. The dissociation can be prevented by a preparation of diaphorase at a concentration equivalent to $0.07 \mu \mathrm{g}$. riboflavin $/ \mathrm{ml}$. Riboflavin is inactive. Mild acid hydrolysis $(N / 20 \mathrm{HCl}$ for $60 \mathrm{~min}$. at $96^{\circ}$ ) does not affect this activity of the diaphorase preparation.

5. It is tentatively suggested that riboflavin phosphate may be the prosthetic group of the enzyme.

I wish to express my sincere thanks to Dr M. Stephenson for her constant encouragement and advice throughout this work; to Miss H. Epps for kindly carrying out the microcarbon determinations; to Drs M. Dixon, E. F. Gale, R. Hill and Prof. Friedmann for much valuable advice; and to Dr Dixon and Dr Hartree for gifts of various nucleotides. I also wish to express my gratitude and thanks to the Medical Research Council for a full-time grant. 


\title{
REFERENCES
}

Abraham, E. P. [1939]. Biochem. J. 83, 543.

Davies, R. [1942]. Biochem. J. 36, 582.

\& Stephenson, M. [1941]. Biochem. J. 35, 1320.

Gale, E. F. \& Epps, H. M. P. [1943]. In the Press.

Green, D. E., Herbert, D. \& Subrahmanyan, V. [1941]. J. biol. Chem. 138, 327.
Kühn, R. \& Rudy, H. [1936]. Hoppe-Seyl. Z. 239, 47.

Van Slyke, D. D. \& Folch, J. [1940]. J. biol. Chem. 136, 509.

Warburg, O. \& Christian, W. [1938a]. Biochem. Z. 298, 150. [1938b]. Biochem. Z. 298, 368.

Weil-Malherbe, H. [1939]. Biochem. J. 33, 1997.

\section{The Influence of Dietary Fat of Varying Unsaturation on the Component Acids of Cow Milk Fats}

\author{
By T. P. HILDITCH, Department of Industrial Chemistry, University of Liverpool, AND \\ H. JASPERSON, Research Department, Messrs J. Bibby and Sons, Ltd., Liverpool
}

(Received 12 December 1942)

In feeding trials in which the basal ration of a group of dairy cows was supplemented by $1 \mathrm{lb}$./day of various fatty oils, Brown, Dustman \& Weakley [1941] observed that the iodine value (i.v.) of the milk fat was altered in different ways by different fats, a feeding period of about 3 weeks being necessary before the extent of the change in i.v. reached its maximum. Coconut oil caused a slight reduction of 4 or 5 units in the i.v. of the milk fat, both crude and refined soya bean oil (i.v. ca. 127) increased it greatly (by over $50 \%$ ), and hydrogenated soya bean oil (i.v. 17) increased it slightly (by about 5 or 6 units), as well as having a pronounced laxative action on the cows. These authors ascribed the slight increase in the unsaturation caused by feeding the hydrogenated oil to desaturation of the fat in the ration, an assumption for which there seems to be no evidence.

Similar alterations in the unsaturation of cow milk fats (as indicated by their i.v.'s alone), which result from administration of specific fats in the diet, have been published. Thus, Holland \& Buckley [1918; 1923] who fed cows on a basal ration, and on the basal ration supplemented by $\frac{3}{4} \mathrm{lb}$. daily of coconut, groundnut, maize or soya bean oils, observed a slight fall in i.v. with the coconut oil diet, but marked increases (35-45\%) with the three liquid fats. Again, Hill \& Palmer [1938] found that the inclusion of maize, cottonseed or linseed oils in the diet increased the i.v.'s, and slightly diminished the Reichert-Meissl values of the corresponding milk fats; tallow slightly increased the milk fat i.v., while butter slightly decreased it, and coconut oil decreased it by 4 or 5 units. Such observations clearly only measure changes in the mean unsaturation of the milk fats, and do not indicate which of the component acids has significantly altered in amount. Thus, whilst oleic acid is the chief unsaturated acid, at least six others may be present in small proportions in cow milk fat, together with nine saturated acids (of which palmitic acid is the chief, though there are appreciable amounts of butyric, myristic and stearic acids). For a clear picture of milk-fat component acids a detailed analysis of the proportions of each acid is necessary.

Few detailed examinations have been made of the effect of supplementary fats in the cow's diet. Hilditch \& Sleightholme [1930] examined milk fats from cows receiving coconut cake or soya bean cake in addition to their normal winter ration; the daily ration of cake ( $7 \mathrm{lb}$. coconut, $5 \mathrm{lb}$. soya bean) could not have contained more (and possibly much less) than 6-7 oz. of fatty oil. The milk fat from cows receiving coconut cake contained less oleic and more lauric and myristic acids than normal, whilst that from animals receiving soya bean cake had somewhat less oleic but the normal amount of octadecadienoic acid, and was otherwise similar to the control milk fats. Hilditch \& Thompson [1936] observed similar effects when $4 \mathrm{oz}$. of linseed, rape or cod-liver oil were added to the daily basal ration of cows. With linseed or rape oils, the component acids differed little, but the proportion of palmitic acid was reduced and that of oleic somewhat increased; with linseed oil, no linolenic acid was present, but the proportion (5.9\% by wt.) of octadecadienoic acids was higher than usual (ca. $3 \%$ ), whilst with rape oil the octadecadienoic acids were normal $(3.3 \%)$ but there was a similar amount of erucic acid. With cod-liver oil the results were more striking: the milk fat here contained an unusually large amount $(5 \cdot 8 \%)$ of highly unsaturated acids 